\title{
EFFECT OF FERMENTED OLIVE MILL WASTE WATER ON THE GROWTH AND PRODUCTIVITY
} OF SORGHUM GROWN UNDER FIELD CONDITIONS

\author{
Ibrahim, Ghada, A. Z. $^{(1)}$; El-Tayeb, T. S. ${ }^{(2)}$; Omar, Amal, M. ${ }^{(1)}$ \\ Balah, M. A. ${ }^{(1)}$ and Ramadan, E. M. ${ }^{(2)}$ \\ 1) Desert Research Center. 2) Faculty of Agriculture, Ain Shams \\ University.
}

\begin{abstract}
Olive mill waste water (OMWW) collected from an olive mill in El Maghara station, Desert Research Center, North Sinai Governorate, Egypt was fermented solely with one of each highly active phenol degrading bacteria namely Enterobacter asburiae and Pseudomonas aeruginosa. The fermented OMWW with E. asburiae or Ps. aeruginosa has a high level of total nitrogen, soluble nutrients (nitrogen and potassium), and low COD, BOD and phenol contentcompared to the unfermented one. Remarkable increases in different microbial counts were detected in the fermented end product than the unfermented one. A field experiment was conducted at Banger El-Sokkar area, Alexandria desert road, Egypt, using sorghum as the task crop to evaluate the fermented OMWW as biofertilizer. The results indicated that the individual addition of the fermented OMWW using $P s$. aeruginosa or E. asburiae as soil drench recorded the highest figures of plant height, fresh weight of shoot, dry weight of shoot, leaf area index and seed weight compared with control.

Application of fermented OMWW also, had a great positive effect on the productivity of sorghum compared to control. Microbiological analysis of rhizosphere soil indicated a remarkable increase in the total microbial counts, nitrogen fixer's counts and Pseudomonas spp. counts in plots treated only with the fermented OMWW either with $E$.
\end{abstract}


asburiae or Ps. aeruginosa comparing with unfermented treatment plots. Using fermented or unfermented OMWW showed positive effect on the chemical composition, sorghum in terms of nitrogen, phosphorus, potassium and carbohydrates.

Results of this experiment clearly indicated that the fermented olive mill waste water can be used as natural liquid organic fertilizer to improve the productivity and chemical constituent of plants when applied as soil drench.

Key word: Olive mill waste water, fermentation, Enterobacter asburiae, Pseudomonas aeruginosa, Sorghum.

\section{INTRODUCTION}

Olive mill waste water can be considered as a pollutant to water and soil as aqueous by-products of olive oil separation. It can be a severe problem when disposed to the soil because of their high organic load, high polyphenols concentration, and moderately low biodegradability (Isidori et al., 2005). At the same time, the large proportion of organic matter and valuable nutrients constitute of OMWW make it a valuable resource as fertilizer particularly in degraded agricultural soils. Thus, elimination of high organic load and polyphenols from the OMWW is a solution for the production of safe fertilizer rich with nutrients. Piperidou et al. (2000) conducted an environmentally friendly bioremediation system of OMWW with high degradation efficiency of toxic constituents. The end product, branded "biofertilizer", was used as soil conditioner and liquid organic fertilizer; two bacterial strains were used as high effective biodegradable bacteria. In another study, Pseudomonas putida was capable of using aromatic 
compounds such as phenol as a sole source of carbon and energy (Movahedyan et al., 2009).

Sorghum is the world's fifth most important cereal crop after maize, rice, wheat and barley. It is cultivated mainly for its grains. Also, sorghum crop residues and green plants provide sources of animal feed and fuel for cooking particularly dry land. Mekki et al. (2006) found the treated plants with OMWW showing an improvement in seed biomass, plant growth, and a similar or even better dry productivity than plants irrigated with water.

Maize growth was significantly promoted by OMWW application reaching more than $10-11 \%$ of the growth of control (Hanifi and Elhadramy, 2007).

The objective of this study was to evaluate fermented olive mill waste water as a potential biofertilizer on sorghum yield and growth parameters under field conditions.

\section{MATERIALS AND METHODS}

Olive mill wastewater: Olive mill waste water (OMWW) samples were collected from an olive mill in El Maghara station, Desert Research Center, North Sinai Governorate, Egypt. Crude OMWW was filtered, diluted to $25 \%(\mathrm{v} / \mathrm{v})$ with distilled water and worked as the unfermented OMWW. For fermented OMWW, the samples were collected for analysis at the end of fermentation process as described later. 
Microorganisms: Enterobacter asburiae or Pseudomonas aeruginosa were isolated from OMWW, according to the method described by Ramsay et al. (1983), and identified according to Bergy's Manual of determinative bacteriology (1994). The identification was confirmed by 16SrRNA sequencing analyses according to (Lane, 1991). Counting of all microbes was after $24 \mathrm{hr}$ except nitrogen fixers after $72 \mathrm{hr}$.

Aerobic fermentation of OMWW: For the biodegradation of phenol content in OMWW, two separate aerobic fermentation processes were performed. For each process, OMWW was diluted to $25 \%(\mathrm{v} / \mathrm{v})$ with tap water andinoculated separately with one of the highly active phenol degrading bacteria. Different experiments were conducted to optimize the fermentation process (Data not shown), the fermentations were conducted under the following conditions which gave maximum phenol degradation: Effluent 20 liter, temperature $25^{\circ} \mathrm{C}$ and $30^{\circ} \mathrm{C}, \mathrm{pH} 6$ and 7 , fermentation time 27 and 30 days with the addition of ammonium sulphate $(0.1 \mathrm{~g} / \mathrm{l})$ as nitrogen source for E. asburiae and Ps. aeruginosa, respectively. The total phenols in the samples were determined every three days according to Ramsay et al. (1983).

\section{Chemical andphysical analyses of unfermented and fermented OMWW:}

The $\mathrm{pH}$ and EC (Electrical Conductivity) of soil and OMWW were measured using an (OAKTON pH-meter) and (YSI MODEL 35 Conductance meter), respectively according to methods of Jacson (1958) and Richards (1954), respectively. Soluble nutrients: N, K, Ca, 
$\mathrm{Mg}$ and $\mathrm{P}$ were determined according to Cottenie et al. (1982). Organic carbon, total nitrogen and total potassium were determined according to the method described by Jacson (1958); Chapman and Pratt (1961) and Bremner and Mulvaney (1982), respectively, BOD $_{5}$ (Biological oxygen demand) and COD (Chemical oxygen demand) analyses were carried out at central laboratory, desert research center. Phenolic compounds were extracted according to the method of De Marco et al. (2006), and then total phenols were determined spectrophotometrecally according to Romero et al. (2002). For this purpose, $1 \mathrm{ml}$ of OMWW and $1 \mathrm{ml}$ of $\mathrm{Na}_{2} \mathrm{CO}_{3}(25 \%)$ were mixed and then added to $0.5 \mathrm{ml}$ folin Ciocalteu reagent, and the volume was made up to $10 \mathrm{ml}$ by distilled water. A calibration curve was established under the same conditions using gallic acid as standard. The optical density (OD) was measured at $730 \mathrm{~nm}$ using a spectrophotometer (Jenway Model 6105 UV Vis spectrophotometer) against a blank.

Chemical analysis: Total nitrogen, phosphorus, potassium and carbohydrate were determined in sorghum straw, leaves, stems and grains according to Jacson (1958), Watanabe and Olsen (1965), Bremner and Mulvaney (1982) and Dubois et al. (1951), respectively.

Microbiological analysis: Counting of different microbial densities in OMWW samples and in the rhizosphere samples of sorghum was conducted on the following media by plate count technique: King's medium (king et al., 1954) for Pseudomonas, Nutrient agar medium (Jacobs and Gerstein, 1960) for total microbial counts, MacConky's 
medium (Windle, 1958) for Enterobacteriacae, Starch nitrate medium (Waksman and Lechevalier, 1962) for Actinomycetes, Yeast Malt agar (Wickerham, 1951) for yeasts and Potato dextrose agar medium (Riker and Riker, 1936) for total fungi.

Ashby's medium (Abd- El - Malek and Ishac, 1968) for asymbiotic nitrogen fixers using Most Probable Number (M.P.N.) technique and counts were estimated using Cochran's tables, Cochran (1950).

Field experiment: To investigate the efficiency of OMWW as soil drench biofertilizer a field experiment was conducted at Banger ElSokkar area - Alexandria desert road, Egypt during summer 2013. The physicochemical analysis of soil was presented in Table (1). Sorghum bicolor (L) var. Hony was the task crop. Field experiment involved 39 plots (13 treatments in 3 replicates) each have $6-\mathrm{m}^{2}$ and thus occupied net area of $234 \mathrm{~m}^{2}$, each plot has five rows. $285 \mathrm{ml} / \mathrm{plot}$ of fermented OMWW were added after 120 days from planting. Two fertilization rates, half and full normal field dose were conducted. The full dose consisted of ammonium nitrate $(33.3 \% \mathrm{~N}) 300 \mathrm{Kg} \backslash \mathrm{fed}$. Calcium super phosphate $\left(15.5 \% \mathrm{P}_{2} \mathrm{O}_{5}\right) 200 \mathrm{Kg} \backslash$ fed. Potassium sulphate $\left(48.5 \% \mathrm{~K}_{2} \mathrm{O}\right)$ $100 \mathrm{KglFadden}$ were used as $\mathrm{N}, \mathrm{P}$ and $\mathrm{K}$ inorganic fertilizers, respectively. Unfermented and fermented OMWW with (E. asburiae) or (Ps. aeruginosa) were added as soil drench $(285 \mathrm{ml} / \mathrm{plot})$. Yield was determined 16 weeks after planting. After harvesting, the following parameters were recorded: Plant height, fresh and dry weight, leaf area, seeds weight and biological yield (grains yield and straw yield). 
$\mathrm{CO}_{2}$ evolution $(\mu \mathrm{g} / \mathrm{g}$ dry soil/ $\mathrm{hr}$.) in the rhizosphere soil were determined according to Pramer and Schmidt (1964).

Statistical analysis: Treatments were arranged in a complete randomized block design. Data were subjected to statistical analysis by ANOVA using the method described by Sndecor (1966): The least significant difference (L.S.D) and Duncan letter at 5\% level of probability was used to differential between the means (Waller and Duncan, 1969).

\section{RESULTS AND DISCUSSION}

Physical and chemical analysis of the used soil at Banger El-Sokkar area:

Results presented in Table (1) showed that the soil chosen for field experiment was sandy calcareous, the results of analysis gave normal values: organic matter $(1.66 \%)$, organic carbon $(0.97 \%)$, total nitrogen $(0.085 \%)$ and $\mathrm{ClN}$ ratio (11.41). The $\mathrm{pH}$ and $\mathrm{EC}$ values were slightly higher. $\mathrm{CaCO}_{3}$ was detected in high percentage being $32 \%$. Sodium and chloride anion showed the highest figures 14.2 and $18.1 \mathrm{meq} / 1$ respectively as compared with other ions.

\section{Chemical, physical and microbiological analysis of unfermented and fermented OMWW:}

Results shown in Table (2) clearly indicated that unfermented OMWW contained high levels of organic matter, COD, BOD, potassium, phosphorus and phenols comparing with the fermented 
OMWW. The fermented samples using Ps. aeruginosa was mostly characterized by a reduction in organic matter, COD, BOD and phenol content. The reduction percentage of $\mathrm{COD}, \mathrm{BOD}$ and phenols were (20\%, $28.07 \%$ and $79.9 \%$ in the application with fermented OMWW E. asburiae) and (48.24\%, 34.22 and $82.6 \%$ for Ps. aeruginosa), comparing with the control. There was no remarkable change in nitrogen content of both fermented OMWW (by E. asburiae 63\% or Ps. aeruginosa 45\%) as compared to control, $\mathrm{pH}$ values increased after fermentation process (7.5 and 6.73 for E. asburiae and Ps. aeruginosa, respectively) compared with unfermented sample (3.8). E.C. increased by Ps. aeruginosa $(6.86 \mathrm{dS} / \mathrm{m})$ and decreased by E. asburiae $(6 \mathrm{dS} / \mathrm{m})$. These results are in agreement with Amhajji et al. (2005), who indicated that the fermentation process was monitored by physicochemical determinations where polyphenols degradation level was (87\%), COD was also reduced by $(60 \%)$, and the $\mathrm{pH}$ of the effluent increased from (4.5 to 6.6). Results also showed that potassium concentration increased in fermented OMWW (4600 and $4670 \mathrm{mgll}$ for E. asburiae and Ps. aeruginosa, respectively), compared to control (unfermented sample $4000 \mathrm{mgl}$ ). The nitrogen content also, increased in fermented OMWW (270 and $284 \mathrm{ppm}$ for E. asburiae and Ps. aeruginosa, respectively) and compared to control (262 ppm). Calcium and phosphorus decreased in fermented OMWW by either E. asburiae or Ps. aeruginosa compared to control. 
The total microbial counts increased slowly during fermentation reaching up to about (116 and $\left.289 * 10^{6} \mathrm{CFU} / \mathrm{ml}\right)$ after 27 and 30 days for either Ps. aeruginosa or E. asburiae, respectively comparing with control (Table 3). The increase in bacterial count during fermentation process would indicate a potent reduction in polyphenols level. The count of Enterobacteriacae were (177 and $\left.292 * 10^{2} \mathrm{CFU} / \mathrm{ml}\right)$, Nitrogen fixers (35 and $144 * 10^{2}$ cells $\left./ \mathrm{ml}\right)$, Pseudomonas spp. (235 and $\left.287 * 10^{2} \mathrm{CFU} / \mathrm{ml}\right)$ and Yeasts $\left(123\right.$ and $\left.27 * 10^{2} \mathrm{CFU} / \mathrm{ml}\right)$ for $P s$. aeruginosa and E. asburiae, respectively which indicated remarkable increase comparing with unfermented OMWW $\left(80^{*} 10^{2} \mathrm{CFU} / \mathrm{ml}\right.$, $0.1 * 10^{6} \mathrm{CFU} / \mathrm{ml}, 6 * 10^{2} \mathrm{CFU} / \mathrm{ml}, 50 * 10^{2} \mathrm{CFU} / \mathrm{ml}$ and $4 * 10^{2} \mathrm{CFU} / \mathrm{ml}$, for total count, nitrogen fixers and Pseudomonas ssp. respectively). These results are in line with those of Amal (2012), who mentioned that the microbial counts of OMWW increased slowly during fermentation reaching up to about $\left(10^{10} \mathrm{CFU} \mathrm{ml}^{-1}\right)$ after 25 days. The results showed that after 25 days, Pseudomonas putida and Pseudomonas fluorescence grown individually were more efficient than Azotobacter vinelandii in degrading phenols at all OMWW concentrations, while a bacterial mixture of the three strains gave the best result. 
Table(1): Physical and chemical analysis of used soil.

\begin{tabular}{|c|c|c|c|c|c|c|c|c|c|c|c|c|}
\hline \multirow[b]{2}{*}{ Location } & \multirow[b]{2}{*}{$\begin{array}{c}\text { Depth } \\
(\mathrm{cm})\end{array}$} & \multicolumn{11}{|c|}{ Physical and chemical analysis } \\
\hline & & $\begin{array}{l}\text { Coarse } \\
\text { sand } \\
(\%)\end{array}$ & $\mathrm{C}+\mathrm{S}(\%)$ & $\begin{array}{l}\text { Clay } \\
(\%)\end{array}$ & $\begin{array}{l}\text { Soil } \\
\text { texture }\end{array}$ & $\mathrm{pH}$ & $\begin{array}{c}\text { Electrical } \\
\text { conductirity } \\
(\mathrm{dS} / \mathrm{m})\end{array}$ & $\begin{array}{c}\text { Organic } \\
\text { matter } \\
(\%)\end{array}$ & $\begin{array}{c}\text { Organic } \\
\text { carbon } \\
(\%)\end{array}$ & $\begin{array}{c}\text { Total } \\
\text { nitrogen } \\
(\%)\end{array}$ & $\begin{array}{l}\mathrm{CN} \\
\text { ratio }\end{array}$ & $\begin{array}{c}\text { Total } \\
\mathrm{CaCO}_{3} \\
(\%)\end{array}$ \\
\hline \multirow{5}{*}{$\begin{array}{l}\text { Banger } \\
\text { El- } \\
\text { Sokkar } \\
\text { area }\end{array}$} & $0-15$ & 93.22 & 5.16 & 1.62 & $\begin{array}{c}\text { Sandy } \\
\text { calcareous }\end{array}$ & 8.21 & 3.13 & 1.66 & 0.97 & 0.085 & 11.41 & 32 \\
\hline & \multicolumn{12}{|c|}{ Cations and Anions (me/l) } \\
\hline & \multicolumn{8}{|c|}{ Cations (meq/) } & \multicolumn{4}{|c|}{ Anions (meq/l) } \\
\hline & & $\mathrm{Ca}^{+2}$ & & $\mathrm{Mg}^{+2}$ & & $\mathrm{Na}^{+}$ & $\mathrm{K}^{+}$ & & $\mathrm{CO}_{3}^{-2}$ & $\mathrm{HCO}_{3}^{-}$ & $\mathrm{Cl}^{-}$ & $\mathrm{SO}_{4}^{-2}$ \\
\hline & & 9.82 & & 5.98 & & 14.2 & 1.24 & & - & 4.3 & 18.1 & 8.84 \\
\hline
\end{tabular}

*Note: The analyses were carried out at central laboratory, desert research center.

Table (2): Physical and chemical properties of fermented and unfermented olive mill waste waters.

\begin{tabular}{|c|c|c|c|c|c|c|c|c|c|c|c|c|c|c|c|}
\hline \multirow{2}{*}{\multicolumn{2}{|c|}{ Treatments }} & \multicolumn{10}{|c|}{ Chemicalproperties } & \multicolumn{4}{|c|}{ Soluble nutrients } \\
\hline & & $\mathrm{ECe}$ & $\mathrm{pH}$ & $\begin{array}{c}\text { Organic } \\
\text { Carbon } \\
(\%) \\
\end{array}$ & \begin{tabular}{|c|} 
Total \\
Nitrogen \\
$(\%)$ \\
\end{tabular} & $\begin{array}{c}\text { Organic } \\
\text { Matter } \\
(\%) \\
\end{array}$ & $\begin{array}{c}C A \\
\text { ratio }\end{array}$ & $\begin{array}{l}\text { BOD } \\
\text { (ppm) }\end{array}$ & $\begin{array}{l}\text { COD } \\
\text { (ppm) }\end{array}$ & $\begin{array}{c}\text { Total } \\
\text { phenols } \\
(\mathrm{ppm})\end{array}$ & $\begin{array}{c}\mathrm{N} \\
\text { (ppm) }\end{array}$ & $\begin{array}{c}P \\
(\%)\end{array}$ & $\begin{array}{c}\mathrm{K}^{+} \\
(\mathrm{ppm})\end{array}$ & $\left(\mathrm{Ca}^{+2} \mathrm{ppm}\right)$ & $\left(\mathrm{Ng}_{\mathrm{g}}^{+1} \mathrm{ppm}\right)$ \\
\hline \multicolumn{2}{|c|}{ control } & 6.71 & 3.8 & 19.6 & 0.6 & 33,3 & 32.7 & 374 & 8332 & 748 & 262 & 0.54 & 4000 & 64 & 43.2 \\
\hline \multirow{2}{*}{\begin{tabular}{|c|} 
Fermented \\
0.IITT" \\
using
\end{tabular}} & \begin{tabular}{|c} 
Enterobacter \\
assurinae
\end{tabular} & 6.0 & 7.5 & 22.6 & 0.98 & 38.4 & 23.1 & 269 & 6664 & 150 & 270 & 0.4 & 4600 & 50 & 36 \\
\hline & $\begin{array}{c}\text { Psendomonoss } \\
\text { aenuginosa }\end{array}$ & 6.86 & 6.73 & 18.1 & 0.87 & 30.7 & 20.8 & 246 & 4312 & 130 & 284 & 0.38 & 4670 & 60 & 45 \\
\hline
\end{tabular}

*OMWW: olive mill wastewater.

*Control: irrigated with unfermented OMWW. 
Table (3): Microbial counts of fermented olive mill waste water.

\begin{tabular}{|c|c|c|c|c|c|c|}
\hline \multicolumn{2}{|c|}{ Treatments } & $\begin{array}{c}\text { Enterobacteriacae } \\
10^{2 *} \mathrm{CFU} / \mathrm{ml}\end{array}$ & $\begin{array}{c}\text { Total count } \\
10^{6 *} \mathrm{CFU} / \mathrm{ml}\end{array}$ & $\begin{array}{c}\text { Nitrogen fixers } \\
10^{2 *} \text { cells } / \mathrm{ml}\end{array}$ & $\begin{array}{c}\text { Yeasts } \\
10^{2 *} \mathrm{CFU} / \mathrm{ml}\end{array}$ & $\begin{array}{c}\text { Pseudomonas } \\
\text { spp. } \\
10^{2 *} \mathrm{CFU} / \mathrm{ml}\end{array}$ \\
\hline \multicolumn{2}{|c|}{ Control } & 80 & 0.1 & 6 & 50 & 4 \\
\hline \multirow{2}{*}{$\begin{array}{l}\text { Fermented } \\
\text { OMWW } \\
\text { using }\end{array}$} & $\begin{array}{c}\text { Enterobacter } \\
\text { asburiae }\end{array}$ & 292 & 289 & 144 & 27 & 287 \\
\hline & $\begin{array}{c}\text { Pseudomonas } \\
\text { aeruginosa }\end{array}$ & 177 & 116 & 35 & 123 & 235 \\
\hline
\end{tabular}

*Control: irrigated with unfermented OMWW.

*OMWW: olive mill wastewater.

\section{Field experiments:}

\section{Plant parameters:}

The inoculation with OMWW fermented by either Ps. aeruginosa or E. asburiae as soil drench recorded the highest results of plant height reaching $(17.64 \%$ and $14.7 \%$ increase for fresh shoot and root, respectively comparing with control), (Table 4). No significant difference was detected in the seed weight among both the tested strains. Lower results were recorded by using unfermented OMWW $(8.82 \%)$ in harvest stage. The addition of unfermented OMWW had a minor positive effect on plant height when added as soil drench. In asimilar study, OMWW- fertilized plots showed a net improvement in plant height of $10-11 \%$ compared with the control. A yield improvement reached $28 \%$ over that of the control when the plants were amended by both land application and foliar spray (Hanifi and ElHadramy, 2007). 
The maximum fresh shoot and root of plants were recorded by inoculation with OMWW fermented by Ps. aeruginosa which represented (60.96 and $74.9 \%$ increase for fresh shoot and root, respectively comparing with control) followed by $E$. asburiae which secured only (49.34 and 53.35\% increase for fresh shoot and root, respectively comparing with control) added as soil drench. Addition of unfermented OMWW had a minor positive effect on fresh weights when added as soil drench (Table 4). In another work as mentioned by Shereen et al. (2011), who studied the effect of using OMWW on morphological and productive characteristics of Manzanillo olive trees grown in a sandy soil. Treated trees with (48 litter of OMWW) induced an apparent significant increase in sex expression fruit set, yield, stone weight and percentage of oil in dry weight of Manzanillo trees.

Significant variations in dry weight of shoot and root were determined among treatments. Maximum dry shoot and root weight were detected with inoculation of OMWW fermented by $P$ s. aeruginosa which represented (79.86 and $67.05 \%$ for dry shoot and root increase, respectively) followed by $E$. asburiae which represented (41.71 and $49.41 \%$ increase for dry shoot and root, respectively) as soil drench comparing with control. Lower results were recorded with using unfermented OMWW comparing with control in harvest stage. Only, the application with unfermented OMWW had a minor positive effect on dry weight of shoot when added as soil drench. In other study, plants treated with OMWW improved seed biomass, plant growth, and a 
similar or even better dry productivity than plants irrigated with water (Mekki et al., 2006).

The maximum leaf area index were recorded by using OMWW fermented by $P$ s. aeruginosa followed by E. asburiae where the percentage increase was 77.77 and $29.55 \%$, respectively comparing with control at harvest stage while the minimum values were observed by using unfermented wastewater $(16.47 \%$ increase, comparing with control). Mild positive effects of unfermented OMWW were recorded (Table 4). The impact of OMWW dilutions (1:10 and 1:20) on Leaf area of spinach declined progressively with decreasing OMWW dilution (Asfi et al., 2012).

The lower seed weight (1000 seeds) in this study was recorded by the use of unfermented OMWW $(26.85 \%$ increase compared with control). This record significantly increased to (80 and 68\%) using either OMWW fermented with Ps. aeruginosa or E. asburiae, respectively compared with control. No significant difference in seed weight was detected among the application with both fermented OMWW. Weight of seeds significantly decreased by using unfermented OMWW inoculation (26.85\%) as comparing with other treatments. Only, addition of unfermented OMWW had a minor positive effect on seed weight when added as soil drench (Table 4). In a comparable study, the application with fermented OMWW by Enterobacter cloacae significantly decreased $\mathrm{pH}$ and increased auxin content and enzyme activities in the rhizosphere soil, and enhanced nutrient concentration in 
shoots and roots of soybean ( $\mathrm{R}_{5}$ stage) and wheat (panicle initiation). At maturity, inoculation significantly enhanced shoots and seeds weight up to 13.77 and $16.09 \%$, respectively, in soybean, and 39.13 and $49.14 \%$ in wheat over un-inoculated control (Ramesh et al., 2014).

\section{2-Straw and grains yield:}

Application of fermented OMWW had a great positive effect on the productivity of sorghum in terms of straw and grains yield compared to control or the unfermented OMWW treatment. The maximum grain yield was detectedby using OMWW fermented by Ps. aeruginosa (80\% increase compared with control), followed by E. asburiae (68\% increase) compared with control (Table 4).

The maximum straw yield was obtained by using OMWW fermented by Ps. aeruginosa (58.9\% increase), followed by E. asburiae (47.9\% increase) compared with control. Lower figures were obtained by using unfermented OMWW (20.58\%) comparing with control in harvest stage (Table 4). According to Ibrahim et al. (2012), who indicated that, the treatment of Beta vulgaris with the amino acids, OMWW or compost tea significantly increased the yield of roots, leaves, sugar comparing with the untreated plots. Both of OMWW and amino acids treatments significantly increased the yield of roots and sugar comparing with compost tea. 


\section{Microbiological analysis:}

There were remarkable increases in the total microbial counts in rhizosphere treated with fermented OMWW comparing with control and unfermented samples (210 and $235^{*} 10^{4} \mathrm{CFU}$ for E. asburiae and Ps. aeruginosa, respectively) (Table 5). This is consistent with data reported by other authors as regards the presence of antimicrobial substances in OMWW. This is also true for both nitrogen fixers (47 and $51 * 10^{4}$ cells/g dry soil for E. asburiae and Ps. aeruginosa, respectively) and Pseudomonas counts which increasedby using fermented OMWW $\left(31 * 10^{4} \mathrm{CFU}\right.$ for E. asburiae) and by Ps. aeruginosa $\left(35^{*} 10^{4} \mathrm{CFU}\right)$, and decreased by using unfermented OMWW $\left(11 * 10^{4} \mathrm{CFU}\right)$ compared to control. The maximum figures of $\mathrm{CO}_{2}$-evolution were obtained by using OMWW fermented with Ps. aeruginosa (80.85\% increase), followed by E. asburiae (65.95\% increase) compared with control. The minimum values were noticed by using unfermented OMWW (32.97\%), comparing with control. The results of $\mathrm{CO}_{2}$ - evolution were parallel with that of microbial counts. Treatment with OMWW increased both the $\mathrm{CO}_{2}$-evolution and microbial counts. Previous studies indicated that the irrigation with waste waters from olive oil extraction increased soil organic matter, $\mathrm{P}, \mathrm{K}$ and $\mathrm{Mg}$ contents and total numbers of microorganisms (Proietti et al., 1995). 
Table (4): Effect of fertilization with fermented and unfermented OMWW on growth parameters of sorghum.

\begin{tabular}{|c|c|c|c|c|c|c|c|c|c|c|}
\hline \multirow{2}{*}{\multicolumn{2}{|c|}{ Treatments }} & \multirow{2}{*}{$\begin{array}{l}\text { Plant } \\
\text { height } \\
(\mathrm{cm})\end{array}$} & \multicolumn{2}{|c|}{ fresh weight (gm) } & \multicolumn{2}{|c|}{ dry weight (gm) } & \multirow{2}{*}{$\begin{array}{l}\text { leaf area } \\
\text { (cm) }\end{array}$} & \multirow{2}{*}{$\begin{array}{c}\begin{array}{l}\text { Weight } \\
\text { (gm of } \\
1000 \\
\text { seeds) }\end{array} \\
\end{array}$} & \multicolumn{2}{|c|}{$\begin{array}{l}\text { Yield parameters } \\
\text { (kglfaddan) }\end{array}$} \\
\hline & & & Shoot & Root & shoot & Root & & & Straw & Grains \\
\hline $\mathrm{C}$ Cor & & $340^{c}$ & $342.24^{d}$ & $28.30^{c}$ & $122.50^{d}$ & $8.50^{b}$ & $210.35^{d}$ & $17.50^{\mathrm{b}}$ & $3901.17^{d}$ & $1837.50^{d}$ \\
\hline Unferment & d OMWW & $370^{\mathrm{b}}$ & $412.83^{c}$ & $35.20^{\mathrm{bc}}$ & $151.70^{c}$ & $10.90^{\mathrm{ab}}$ & $245^{c}$ & $22.20^{\mathrm{b}}$ & $4704.31^{c}$ & $2331.00^{\mathrm{C}}$ \\
\hline \multirow{2}{*}{$\begin{array}{c}\text { Fermented } \\
\text { OMWW } \\
\text { using }\end{array}$} & E. asburiae & $390^{\mathrm{a}}$ & $511.13^{b}$ & $43.40^{\mathrm{ab}}$ & $173.60^{\mathrm{b}}$ & $12.70^{\mathrm{a}}$ & $272.52^{b}$ & $29.40^{\mathrm{a}}$ & $5770.06^{b}$ & $3087.00^{b}$ \\
\hline & $\begin{array}{c}\text { Ps. } \\
\text { aeruginosa }\end{array}$ & $400^{\mathrm{a}}$ & $550.9^{\mathrm{a}}$ & $49.50^{\mathrm{a}}$ & $220.34^{\mathrm{a}}$ & $14.20^{\mathrm{a}}$ & $373.96^{\mathrm{a}}$ & $31.50^{\mathrm{a}}$ & $6199.20^{\mathrm{a}}$ & $3307.50^{\text {a }}$ \\
\hline \multicolumn{2}{|c|}{$\operatorname{LSD}(0.05)$} & 12.97 & 20.23 & 11.74 & 13.87 & 3.75 & 11.31 & 6.18 & 67.84 & 33.39 \\
\hline
\end{tabular}

*Control: irrigation with tap water only.

*OMWW: olive mill wastewater.

*Mean representing the effect of each factor on a particular parameter and not followed by the same litter are significantly different by Duncan's multiple range test $(\mathrm{P}<0.05)$.

Table (5): Microbial counts and $\mathrm{CO}_{2}$ evolution in the rhizosphere soil of Sweet sorghum at harvest stage.

\begin{tabular}{|c|c|c|c|c|c|}
\hline \multicolumn{2}{|c|}{ Treatments } & $\begin{array}{l}\text { Total } \\
\text { count } \\
\left(10^{4 *}\right. \\
\text { CFU/ } \\
\text { g) }\end{array}$ & $\begin{array}{l}\text { Nitrogen } \\
\text { fixers }\left(10^{4} *\right. \\
\text { cells/g dry } \\
\text { soil) }\end{array}$ & $\begin{array}{c}\text { Pseudomonas } \\
\text { spp. } \\
\left(10^{4} * \text { CFU/g }\right)\end{array}$ & $\begin{array}{c}\mathrm{CO}_{2^{-}} \\
\text {evolution }(\mathrm{mg}) \\
\text { 100g dry soil } \\
\text { /hr) }\end{array}$ \\
\hline \multicolumn{2}{|c|}{ Control } & 186 & 30 & 22 & 0.47 \\
\hline \multicolumn{2}{|c|}{ Unfermented OMWW } & 161 & 9 & 11 & 0.315 \\
\hline \multirow{2}{*}{$\begin{array}{l}\text { Fermented } \\
\text { OMWW } \\
\text { using }\end{array}$} & E. asburiae & 210 & 47 & 31 & 0.78 \\
\hline & $\begin{array}{c}\text { Ps. } \\
\text { aeruginosa }\end{array}$ & 235 & 51 & 35 & 0.85 \\
\hline
\end{tabular}

*Control: irrigated with tap water only.

*OMWW: olive mill wastewater. 


\section{Chemical composition of plants:}

\section{Total nitrogen, phosphorus and potassium (NPK):}

Generally total NPK in grains were higher than that in leaves and stem. It was indicated that addition of unfermented or fermented OMWW had positive effect on NPK content of sorghum plants when added as soil drench. For N, no significant differences among the treatments were detected (Table 6). For phosphorus and potassium, using fermented OMWW were more effective than that of unfermented one, while no difference was detected between E. asburiae or Ps. aeruginosa $(0.18$ and $0.17 \%$ of phosphorus in grains to each microbe, respectively), while potassium concentration in grains were (0.51 and $0.55 \%$ ) for each microbe, respectively. In another work, the total nitrogen, phosphate and potassium in plants increased proportionally to the amounts of untreated OMWW (Belaqziz et al., 2008). Total nitrogen, phosphorus, sodium, and potassium in soil were found to be increased with increasing OMWW supply (Chaari et al., 2014).

\section{Chlorophyll content:}

Chlorophyll content in fresh leaves was determined at the end of Sweet sorghum plant growth. The maximum chlorophyll content at harvest stage of Sweet sorghum was detected in plants inoculated with fermented OMWW comparing with unfermented OMWW (43.09 and $52.76 \%$ increase for E. asburiae and Ps. aeruginosa, respectively). Unfermented OMWW had a minor positive effect (11.87\%) compared to control (Table 6). 
J. Environ. Sci.

Institute of Environmental Studies and Research - Ain Shams University

\section{Total carbohydrates}

Data in Table (6) show also that the maximum total carbohydrates was recorded by using the individual application of fermented OMWW as soil drench by either Ps. aeruginosa or E. asburiae (79.28\% and $52.72 \%$ increase), followed by unfermented OMWW (35.45\%) comparing with control.

\section{Total phenols:}

Total phenols were recorded in all parts of plant; the maximum concentrations were determined in grains followed by leaves while stems recorded the lowest concentrations as shown in Table (6). Results also indicated that there were significant differences among the treatments; the lowest figures were obtained by using fermented OMWW as soil drench by Ps. aeruginosa followed by E. asburiae, and then by unfermented OMWW comparing with control which recorded the maximum values. In another study, the phenolic acids reported in cereals occur in both free and bound forms. Sorghum and millet have the widest variety of phenolic acids. The major phenolic acids in cereals are ferulic and p-coumaric acids. Phenol compounds in grains of sorghum were ranged from 385-746 $\mathrm{mg} \backslash \mathrm{g}$ as reported by (McDonough et al., 2000, Zhou et al., 2004, Mattila, et al., 2005, Holtekjolen et al., 2006).

\section{CONCLUSION}

The fermented system eliminates the phytotoxic principles of OMWW and concomitantly enriches it with an agriculturally beneficial microbial consortium and useful metabolites. The end product can be 
used as biofertilizer which stimulate the growth, yield and chemical composition of plants when added to plants as soil drench.

Table (6): Effect of unfermented or fermented olive mill wastewater on chemical constituents of Sweet sorghum plants at harvest stage.

\begin{tabular}{|c|c|c|c|c|c|c|c|c|c|c|c|c|c|c|}
\hline \multirow{2}{*}{ Treatments } & \multicolumn{3}{|c|}{ NITROGEN $(\%)$} & \multicolumn{3}{|c|}{ PHOSPHORUS (\%) } & \multicolumn{3}{|c|}{ POTASSITM(\%) } & \multirow{2}{*}{$\begin{array}{c}\text { Chloroph } \\
\text { yll } \\
\end{array}$} & \multirow{2}{*}{$\begin{array}{c}\text { Carbohydrates } \\
(\%)\end{array}$} & \multicolumn{3}{|c|}{ Total phenols $(\mathrm{mg} / \mathrm{g})$} \\
\hline & stem & leares & grain & stem & leares & grains & stem & leares & grins & & & stem & leares & grains \\
\hline Control & $0.2^{b}$ & $0.4^{b}$ & $0.4^{b}$ & $0.022^{2}$ & $0.03^{b}$ & $0.04^{b}$ & $0.1^{b}$ & 0.25 & $0.35^{5}$ & $36.2^{b}$ & $7.53^{b}$ & $120^{d}$ & $210^{b}$ & $300^{b}$ \\
\hline Unfermented 0.MTWW & $0.31^{1}$ & $0.57^{16 \mathrm{~b}}$ & $0.6^{1}$ & $0.05^{4}$ & $0.05^{5}$ & $0.1^{1 b}$ & $0.2^{2 \mathrm{~b}}$ & $0.33^{k}$ & $0.55^{\mathrm{k}}$ & $40.5^{b}$ & $10.2^{2 b}$ & $217^{\mathrm{x}}$ & $296^{1}$ & $333^{4}$ \\
\hline \begin{tabular}{|c|c||} 
Fermented & Enterobacter \\
asburiae
\end{tabular} & $0.34^{4}$ & $0.68 \mathrm{~s}$ & $0.8^{8}$ & $0.1^{1}$ & $0.12^{2}$ & $0.18^{2}$ & $0.4^{2}$ & $0.5^{5 b}$ & $0.51^{1}$ & 51.84 & $11.5^{5}$ & $154^{i}$ & $286^{\circ}$ & $286^{\circ}$ \\
\hline \begin{tabular}{cc|}
$\begin{array}{c}\text { U.Mmin } \\
\text { using }\end{array}$ & $\begin{array}{c}\text { Pseuddomonas } \\
\text { aeruginosa }\end{array}$ \\
\end{tabular} & $0.377^{7}$ & $0.71^{1}$ & $1.0^{2}$ & $0.11^{x}$ & $0.13^{3}$ & $0.17^{2}$ & $0.3^{3 \mathrm{bb}}$ & $0.55^{\circ}$ & $0.55^{2}$ & $55.3^{2}$ & $13,5^{4}$ & $177^{\mathrm{b}}$ & $290^{k}$ & $290^{\circ}$ \\
\hline $\operatorname{LSD}(0.05)$ & 0.103 & 0.19 & 0.58 & 0.095 & 0.033 & 0.098 & 0.24 & 0.21 & 0.217 & 7.10 & 3.49 & 6.17 & 7.10 & 8.73 \\
\hline
\end{tabular}

*Control: irrigation with tap water only.

*OMWW: olive mill wastewater.

* Mean representing the effect of each factor on a particular parameter and not followed by the same litter are significantly different by Duncan's multiple range test $(\mathrm{P}<0.05)$.

\section{REFERENCES}

Abd-El-Malek, Y. and Ishac, Y.Z. (1968): Evaluation of methods used in counting Azotobacter .J. Appl. Bacteriol., 31:267 - 275.

Amal, M. O. (2012): Production of Organic Biofertilizer from Olive Mill Waste Water.Australian J. Basic and App. Sci., 6: 654-663.

Amhajji, A.; Faid, M. and El-Yachioui, M. (2005): A process for the treatment of Olive Mill waste waters by immobilized cells. Grasas y Aceites Sevilla, 56: 121-124. 
J. Environ. Sci.

Institute of Environmental Studies and Research - Ain Shams University

Asfi, M.; Ouzounidou, G.; Panajiotidis, S.; Therios, I. \& Moustakas, M.

(2012): Toxicity effects of olive-mill wastewater on growth, photosynthesis and pollen morphology of spinach plants. Ecotoxicol. Environ. Saf., 80:69-75.

Belaqziz, M.; Lakhal, E.K.; Mbouobda, H.D. \& El Hadrami, I. (2008): Land Spreading of Olive Mill Wastewater Effect on Maize (Zea maize) Crop. J. Agrono., 7: 297-305.

Bergy's Manual of Determinative Bacteriology (1994): John G. Hol, Noel R. Kriey, Peter H.A. Sneath, Jamest-Staley T. Williams (eds) (Nint1 edition) Williams \& Wilkins, Baltimore, London.

Bremner, J.M. \& Mulvaney, C.S. (1982): Nitrogen. In: Page, A.L., Miller, R.H. and Keeney, D.R. (Eds.), Methods of soil analysis. Part 2, Chemical and microbiological properties. Agron. 9, Soc. Agron., Madison, Wisconsin, 595-624.

Chaari, L.; Elloumi, N.; mseddi, S.; Gargouri, K.; Bourouina, B.; Mechichi, T. \& Kallel, M. (2014): Effects of Olive Mill Wastewater on Soil Nutrients Availability. Internat. J. Interdisciplinary \& Multidisciplinary Studies, 2: 175-183.

Chapman, H. D. \& Pratt, P. F. (1961): Methods of analysis soils, plant and waters. Univ. of California, Division Agric. Sci. Riverside, California. USA.

Cochran, W. G. (1950): Estimation of bacterial densities by mean of the Most Probable Number.Biometrics, 6:105-115.

Cottenie, A. L.; Verloo, L.; Kiens, L.; Velghe, G. \& Camerlynch, R. (1982): Chemical analysis of plant and soil. Lab. of Analytical and Agrochemistry, State Univ., Ghent, Belgium.

Dubios, M.K.; Gilles, J.K.; Robers, P.A. \& Smith, F. (1951): Colorimetric determination of sugar and related substance. Analyt. Chem., 351-356.

De Marco, E.; Savarese, M.; Paduano, A. \& Sacchi, R. (2007): Characterization and fractionation of phenolic compounds 
extracted from olive oil mill waste waters. Food Chem., 104: 858-867.

Hanifi, S. \& El Hadramy, I. (2007): Phytotoxicity and fertilising potential of olive mill wastewaters for maize cultivation. J. Agron., 28: 112-121.

Holtekjolen, A.K.; Kinitz, C. \& Knutsen, S.H. (2006). Flavanol and bound phenolic acid contents in different barley varieties.J. Agric. Food Chem., 54:2253.

Ibrahim, Sh. M.; Ibrahim Heba A.K. \& Omer Amal M. (2012).Comparative Study of the Effects of Some Organic Extract on Sugar Beet Yield Under Saline Conditions.Australian J. Basic \& App. Scie., 6: 664-674.

Isidori, M.; Lavorgna, M.; Nardelli, A. \& Parrella, A. (2005). Model study on the effect of 15 phenolic olive mill wastewater constituents on seed germination and Vibrio fischeri metabolism. J. Agric. And Food Chem., 53: 8414-8417.

Jacson, M.L. (1958). Soil chemical analysis. Prentice-Hall, Inc., England, Cliffs, J. Plant nutrition and soil sci., 85: 251252.

Jacobs, M.B. \& Gerstein, M.J. (1960). Hand Book of Microbiology. De.VanNostranal Co. Inc., New York, 139 - 202.

King, E.O.; Wand, M.K. \& Raney, O.E. (1954).Two simple media for the demonstration of pyocyanin and fluorescein. J. Lab. Clin. Med., 44: 301 - 307.

Lane, D.J. (1991). 16S/23S rRNA sequencing. In: Stackebrandt E of Goodfellow M (editors). Nucleic acid techniques in bacterial systematics. Chichester: John Wiley \& Sons.,115-175. 
J. Environ. Sci.

Institute of Environmental Studies and Research - Ain Shams University

Mattila, P.; Pihlava, J.M. \& Hellstrom, J. (2005): Contents of phenolic acids, alkyl- and alkenylresorcinols, and avenanthramides in commercial grain products. J. Agric. Food Chem., 53:8290.

McDonough, C.M.; Rooney, L.W.; Serna-Saldivar, S.O.; Kulp, K.; Ponte, J.G. \& Dekker, M. (2000) :The millets. Handbook of Cereal Sci. and Techn. Inc., New York, 177-201.

Mekki, A.; Dhouib, A. \& Sayadi, S. (2006): Changes in microbial and soil properties following amendment with treated and untreated olive mill wastewater.Microb. Res., 161,93-101.

Movahedyan, H.; Khorsandi, H.; Salehi, R. \& Nikaeen, M. (2009): Detection of phenol degrading bacteria and Pseudomonas putida in activated sludge by polymerase chain.Iran. J. Environ. Health.Sci. Eng., 6:115- 120.

Parmer, D. \& Schmidt, E.L. (1964): Experimental soil microbiology, Burges pub .Co. Minnesota, U.S.A.

Piperidou, C. I.; Chaidou, C. I.; Stalikas, C. D.; Soulti, K.; Pilidis, G. A. \& Balis, C. (2000): Bioremediation of olive oil mill wastewater: chemical alterations induced by Azotobacter vinelandii. J. Agric. and Food Chem., 48: 1941-8.

Proietti, P.; Palliotti, A.; Tombesi, A. \& Cenci, G. (1995): Chemical and microbiological modifications of two different cultivated soils induced by olive oil waste water administration. Agric. Mediterranea, 125: 160-171.

Ramesh, A.; Sushil, K.; Sharma, Sh. M.P.; Namrata, Y. \& Joshi, Om P. (2014): Plant Growth-Promoting Traits in Enterobacter cloacae subsp. dissolvens MDSR9 Isolated from Soybean Rhizosphere and its Impact on Growth and Nutrition of Soybean and Wheat Up on Inoculation. Agric. Research, 3: 53-66.

Ramsay, B.A.; Cooper, D.G.; Margaritis, A. \& Zajic, J.E. (1983): Rhodochorous bacteria: Biosurfactant production and Demulsifying Microbial Enhanced oil Recovery. Penn Well Books, 61 - 65. Tulsa, Oklahoma. 
Richards , L. A. (1954): Diagnoses and improvement of saline and alkaline soils. U.S.A. Dept. Agric. Handbook No. (60)17133.

Riker, A. J. \& Riker R. S. (1936). Introduction to research on plant diseases. St. Louis, Chicago, New York, Johns Sweift Co., p. 117.

Romero, C.; Brenes, M.; Garcl 'a, P. \& Garrido, A. (2002): Hydroxytyrosol 4-D- glucoside, an important phenolic compound in olive fruits and derived products. J. Agric. Food Chem., 50: 3835-3839.

Shereen, Sh. A.; El - Taweel, Sh. \& Al-Khateeb, A. (2011): Effect of Using Olive Vegetation Water (OVW) on Growth, Flowering and Yield of Manzanillo Olive Trees. J. American Sci., 7:501-510.

Sndecor, G.W. (1966). Statistical Methods.The state Univ. Press. Ames. IOWa, U.S.A.PP.534.

Waksman, S.A. \& Lechevalier, H. (1962): “The Actinomycetes" Vol. Ш Antibiotics of Actinomycetes. Baltimore. The Williams and Wilkins Company USA.

Waller, R.A. \& Duncan, B.D. (1969): A way for the symanetric Multiple comparison problem. J. Amer. State. Assoc., 3: $1485-1503$.

Watanabe, F. S., and. Olsen, S. R. (1965): Test of an ascorbic acid method for determining phosphorus in water and $\mathrm{NaHCO}_{3}$ extracts from soil. Soil Sci. Soc. Amer. Pro., 29:677-678.

Wickerham, L.J. (1951): Taxonomy of Yeasts. Tech. Bull. No. 1029, US Dept. Agric., Washington D.C. USA.

Windle, T.E. (1958): The examination of waters and water supplies. $7^{\text {th }}$ ed, Church; Ltc. London.

Zhou, Z.; Robards, K.; Helliwell, S. \& Blanchard, C. (2004): The distribution of phenolic acids in rice. Food Chem., 87:401. 


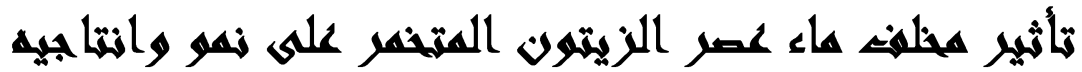

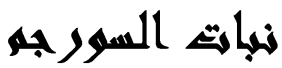

\section{$[1 \cdot]$}

غادة أمين زكى إبر اهيم(')- طارق سعيد الطيب(†) أمل محمد عمر سالم (')

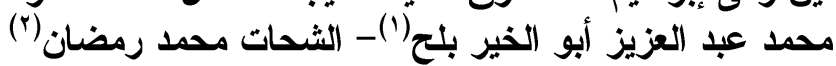

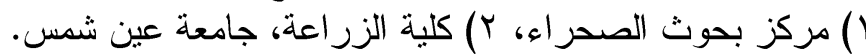

\section{المستخلص}

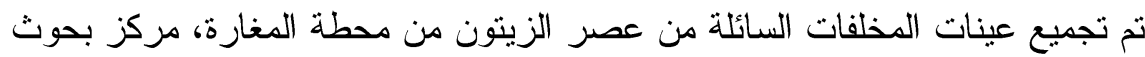

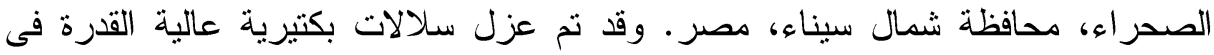
تكسير الفينولات و التى نم تعريقها الى Enterobacter asburiae و Pseudomonas aeruginosa

وقد اوضحت النتائج ان المخلف المتخمر من ماء عصر الزيتون باستخدام الانتيروباكتر او السيدوموناس احتوى على اعلى معدلات من النيتروجين الكلى، ومن بلى النين

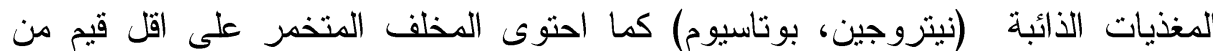

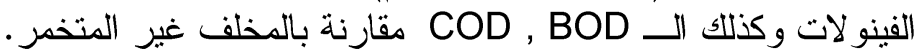
سجلت اعداد مختلف المجموعات الميكروبية زيادة فى المخلف المتخمر عنه في في غير

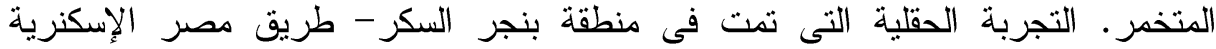

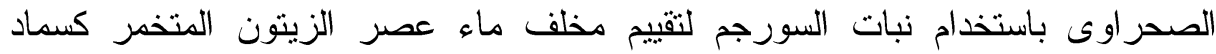

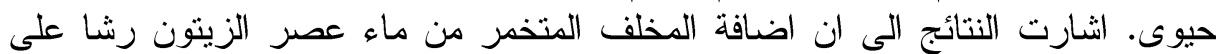

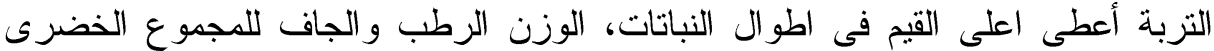

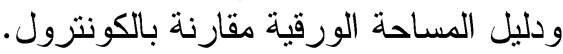

بتطبيق المخلف المتخمر من ماء عصر الزيتون واستخدامه كسماد حيوى ايضا فإن له له

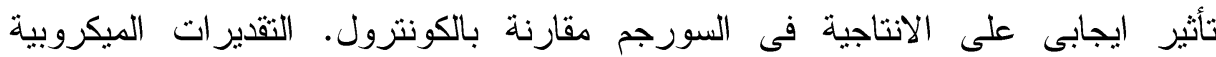

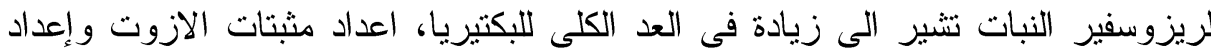

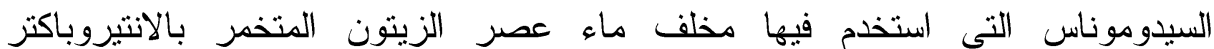

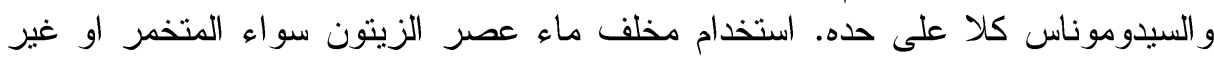

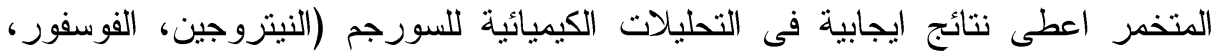
البو تاسيوم و الكربو هيدر اتج). 


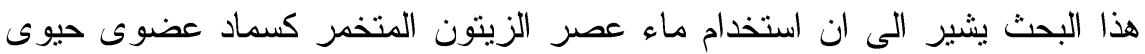
طبيعى سائل يحسن الانتاجية و المكونات الكيميائية للنبات اذاذ ما استخدم رشا على النى الاوراق. 